\title{
Allele-Specific PCR for the Detection of Azoxystrobin Resistance in Didymella bryoniae
}

Mavis J. Finger, Venkatesan Parkunan, Pingsheng Ji, and Katherine L. Stevenson, Department of Plant Pathology, University of Georgia, Tifton 31793

\begin{abstract}
Finger, M. J., Parkunan, V., Ji, P., and Stevenson, K. L. 2014. Allele-specific PCR for the detection of azoxystrobin resistance in Didymella bryoniae. Plant Dis. 98:1681-1684.

Gummy stem blight (GSB), caused by the fungus Didymella bryoniae, is considered the most widespread and destructive disease of watermelon in the southeastern United States. The quinone outside-inhibiting (QoI) fungicide azoxystrobin (AZO), which inhibits mitochondrial respiration by binding to the outer, quinone-oxidizing pocket of the cytochrome bc1 (cyt b) enzyme complex, was initially very effective in controlling GSB. However, resistance to AZO has been observed in $D$. bryoniae in many watermelon-producing regions. In this study, the DNA sequences of partial cyt $b$ genes of four AZO-resistant (AZO-R) and four AZO-sensitive (AZO-S) isolates of D. bryoniae confirmed the

amino acid substitution of glycine by alanine at the 143 codon (G143A) in the AZO-R isolates tested. Allele-specific primers were designed to detect the resistant or sensitive allele at codon 143 of the cyt $b$ gene, which amplified a 165 -bp polymerase chain reaction (PCR) product from genomic DNA of nine AZO-R and nine AZO-S isolates of D. bryoniae, respectively. The primer pairs did not amplify DNA from other pathogens tested in the study. The results indicated that the PCR assays developed in the study were specific in differentiating AZO-R and AZO-S isolates and could facilitate AZO resistance detection in D. bryoniae.
\end{abstract}

Gummy stem blight (GSB), caused by the fungus Didymella bryoniae (Fuckel) Rhem, is considered the most widespread and destructive disease of watermelon (Citrullus lanatus (Thunb.) Matsum. \& Nikai) in Georgia and other southeastern U.S. states $(9,22)$. The pathogen infects all aboveground plant parts. Typical symptoms appear as dark-brown, irregularly shaped lesions with a concentric ring pattern that occur near the leaf margins and in the interveinal regions. Lesions may also be found on stems and may expand and girdle the main stem, creating a canker. GSB is primarily controlled using a combination of cultural practices and chemical fungicides. Although cultural practices play an important role in GSB management, they are less efficacious when used alone. When disease pressure is high, fungicides with protective and systemic properties are essential for the successful management of GSB.

The quinone outside inhibitor (QoI) fungicide azoxystrobin (AZO) has been used for control of GSB. QoI fungicides inhibit mitochondrial respiration by binding to the outer, quinone-oxidizing pocket of the cytochrome bc1 ( $c y t b)$ enzyme complex which, in turn, blocks electron transport and results in energy loss in the fungus (6). With the heavy reliance on systemic fungicides with site-specific modes of action, disease control failures related to fungicide resistance have been noted in several fungal pathogens $(3,8,11,15,18,21)$. In particular, rapid evolution of fungicideresistant isolates of $D$. bryoniae to AZO was reported within a year of registration of the fungicide for use in commercial watermelon production $(12,13,22)$. Most recently, resistance frequencies of up to $100 \%$ have been reported in untreated control plots (23).

The rapid development of resistance to QoI fungicides in fungal plant pathogens has been attributed to a substitution of alanine for glycine at amino acid position 143 (G143A) (6). Substitution of leucine for phenylalanine at amino acid position 129 (F129L) and a substitution of arginine for glycine at amino acid position 137

Corresponding author: P. Ji, E-mail: pji@uga.edu

Accepted for publication 23 May 2014.

http://dx.doi.org/10.1094/PDIS-02-14-0136-RE

(C) 2014 The American Phytopathological Society
(G137R) also confer resistance to QoI fungicides in some fungi (4). However, the F129L and G137R mutations have been associated with a lower level of fungicide resistance and do not seriously affect field performance of QoI fungicides (4). In D. bryoniae, the rapid development of QoI-fungicide-resistant isolates has been attributed to the G143A mutation (5). However, the sequence of the G143A region of the cyt $b$ gene in $D$. bryoniae has not been published.

QoI resistance monitoring can be accomplished using traditional fungicide sensitivity assays or through molecular techniques. Currently, the detection of AZO resistance in D. bryoniae is accomplished using conidial germination assays on fungicide-amended medium. Although conidial germination assays are useful in resistance monitoring, these assays are time consuming and labor intensive. Molecular-based detection of resistance would significantly decrease the time and labor required to monitor $\mathrm{AZO}$ resistance development. Therefore, the objectives of this study were to sequence the cyt $b$ G143A region of $D$. bryoniae isolates, confirm the mutation in the cyt $b$ of $D$. bryoniae isolates resistant to $\mathrm{AZO}$, and develop a rapid, allele-specific polymerase chain reaction (PCR) assay to detect AZO resistance.

\section{Materials and Methods}

Fungal isolates. Eighteen single-lesion isolates of $D$. bryoniae were used in this study. The isolates were previously collected in 2010 by Thomas et al. (23) from field-grown watermelon plants showing symptoms of GSB in different counties in Georgia (Table 1). Each isolate was previously characterized as AZO-resistant (AZO-R) or AZO-sensitive (AZO-S) using a conidial germination assay with a discriminatory AZO concentration of $10.0 \mu \mathrm{g} / \mathrm{ml}$ and salicylhydroxamic acid (SHAM) at $100 \mu \mathrm{g} / \mathrm{ml}$ (23). Isolates exhibiting greater than $50 \%$ relative germination on fungicide-amended medium were considered AZO-R (23). Isolates were grown for 1 to 2 weeks on PDA with small pieces of sterilized filter paper placed on the surface. Colonized filter paper pieces were removed from the plates, air-dried, and then kept at $-20^{\circ} \mathrm{C}$. Before use, the isolates were assayed again using methods described by Thomas et al. (23) to confirm sensitivity to AZO.

Genomic DNA extraction. $D$. bryoniae isolates were grown in $50 \mathrm{ml}$ of potato dextrose broth at $24^{\circ} \mathrm{C}$ for 4 days with continuous shaking (100 rpm). Mycelia were harvested (about 100 to $200 \mathrm{mg}$ 
fresh weight), frozen in liquid nitrogen, and then ground into a fine powder using a mortar and pestle. Genomic DNA (gDNA) was extracted from each isolate using a DNeasy Plant Mini kit (Qiagen), following the manufacturer's instructions. DNA concentrations were measured using a NanoDrop 2000 spectrophotometer and adjusted to $50 \mathrm{ng} / \mu \mathrm{l}$. DNA was stored at $-20^{\circ} \mathrm{C}$ until further use.

Partial sequencing of the gDNA cyt $b$ of $D$. bryoniae. Four AZO-R and four AZO-S isolates were used for partial sequencing of $c y t b$ in genomic DNA. The primers FG143 and RG143 (Table 2), designed previously by Patel et al. (20) for Pyrenophora triticirepentis, amplified a fragment of the $c y t b$ containing the amino acid 143 codon in all eight isolates of $D$. bryoniae. The PCR was performed in a $25-\mu$ l volume containing $2.5 \mu \mathrm{l}$ of $10 \times$ PCR buffer, $0.5 \mu \mathrm{l}$ of $10 \mathrm{mM} \mathrm{dNTP}, 1.5 \mu \mathrm{l}$ each of the $10 \mu \mathrm{M}$ forward and reverse primers, $0.2 \mu \mathrm{l}$ ( 1 unit) of Taq polymerase, and $2 \mu \mathrm{l}$ of template DNA (50 ng/ $\mu \mathrm{l})$. All PCR reactions were run in a Bio-Rad T100 Thermal Cycler. The PCR conditions were modified from those reported by Patel et al. (20) as follows: an initial preheat for $5 \mathrm{~min}$ at $95^{\circ} \mathrm{C}$; followed by 35 cycles of denaturation at $94^{\circ} \mathrm{C}$ for $30 \mathrm{~s}$, annealing at $55^{\circ} \mathrm{C}$ for $30 \mathrm{~s}$, and extension at $72^{\circ} \mathrm{C}$ for $1 \mathrm{~min}$;

Table 1. Source of Didymella bryoniae isolates used in this study ${ }^{\mathrm{a}}$

\begin{tabular}{lcc}
\hline Isolate & Georgia county & AZO sensitivity \\
\hline C2-8 & Tift & $\mathrm{S}$ \\
R204-1-1 & Tattnall & $\mathrm{S}$ \\
UR3-5 & Tattnall & $\mathrm{S}$ \\
R501-3-1 & Tattnall & $\mathrm{S}$ \\
R501-3-2 & Tattnall & $\mathrm{S}$ \\
R501-3-4 & Tattnall & $\mathrm{S}$ \\
R501-3-5 & Tattnall & $\mathrm{S}$ \\
R606-3-1 & Tattnall & $\mathrm{S}$ \\
R606-3-4 & Tattnall & $\mathrm{S}$ \\
C2-1 & Tift & $\mathrm{R}$ \\
B105-3-3 & Tift & $\mathrm{R}$ \\
C5-1 & Tift & $\mathrm{R}$ \\
C2-5 & Tift & $\mathrm{R}$ \\
C2-7 & Tift & $\mathrm{R}$ \\
C5-7 & Tift & $\mathrm{R}$ \\
C5-8 & Tift & $\mathrm{R}$ \\
UR3-1 & Tattnall & $\mathrm{R}$ \\
UR5-9 & Tattnall & $\mathrm{R}$
\end{tabular}

${ }^{\mathrm{a}}$ Isolates were collected in 2010 from watermelon fields by Thomas et al. (23).

${ }^{\mathrm{b}}$ Previously determined using in vitro fungicide sensitivity assay by Thomas et al. (23). Isolates exhibiting $>50 \%$ relative germination (RG) on azoxystrobin (AZO)-amended medium at a discriminatory concentration of $10.0 \mu \mathrm{g} / \mathrm{ml}$ were considered resistant (R). Isolates exhibiting $<50 \% \mathrm{RG}$ were considered sensitive (S). and a final extension at $72^{\circ} \mathrm{C}$ for $10 \mathrm{~min}$. PCR products were examined by electrophoresis in a $1 \%$ agarose (Fisher Scientific) gel in Tris-borate-EDTA buffer. The gel was amended with $1 \times$ GelRed nucleic acid gel stain (Biotium, Inc.) and visualized directly in a BioRad Chemi XRS Gel Documentation system (Bio-Rad). The PCR products were purified using QIAquick PCR Purification kit (Qiagen), according to the manufacturer's instructions. The purified PCR products were sent for direct sequencing in both directions (Eurofins MWG Operon). The sequences obtained from the four AZO-R and four AZO-S isolates were compared using the Clustal Omega program (http://www.ebi.ac.uk/Tools/msa/clustalo/).

Development of $D$. bryoniae allele-specific PCR primers for detection of AZO resistance. The primer sets DB-F/DB-RR and DB-F/DB-RS (Table 2) were designed and used to amplify the $c y t$ $b$ sequences with and without the G143A mutation, respectively, by matching the desired allele and mismatching the other allele at the $3^{\prime}$ end of the primer. The reverse primers DB-RR and DB-RS were designed so that they contained a $\mathrm{C}$ or $\mathrm{G}$ nucleotide, respectively, at the first position at the $3^{\prime}$ end. A third primer set, DBFC/DB-RC (Table 2), was designed to amplify both alleles.

To confirm species specificity of the primer sets DB-F/DB-RR, DB-F/DB-RS, and DB-FC/DB-RC, nine AZO-R and nine AZO-S $D$. bryoniae isolates and other fungal species isolated from watermelon, including Pythium ultimum, Phytophthora capsici, Fusarium oxysporum f. sp. niveum, Sclerotium rolfsii, Rhizoctonia solani, and Pseudoperonospora cubensis, were tested. Genomic DNA was extracted from all species as described above.

All PCR amplifications were performed in a $25-\mu l$ volume containing $2.5 \mu \mathrm{l}$ of $10 \times$ PCR buffer, $0.5 \mu \mathrm{l}$ of $10 \mathrm{mM}$ dNTP, $2 \mu \mathrm{l}$ each of the $10 \mu \mathrm{M}$ forward and reverse primers, $0.2 \mu \mathrm{l}$ (1 unit) of Taq polymerase, and $2 \mu \mathrm{l}$ of template DNA $(50 \mathrm{ng} / \mu \mathrm{l})$. The PCR conditions were as follows: an initial preheat for $3 \mathrm{~min}$ at $95^{\circ} \mathrm{C}$; followed by 25 cycles of denaturation at $95^{\circ} \mathrm{C}$ for $10 \mathrm{~s}$, annealing at $60^{\circ} \mathrm{C}$ for $10 \mathrm{~s}$, and extension at $72^{\circ} \mathrm{C}$ for $15 \mathrm{~s}$; and a final extension at $72^{\circ} \mathrm{C}$ for $3 \mathrm{~min}$. PCR products were examined by electrophoresis, as described earlier.

\section{Results}

Analysis of partial $c y t \boldsymbol{b}$ sequence of $D$. bryoniae gDNA. The primers FG143 and RG143 amplified a single approximately 265bp DNA fragment in the four AZO-R isolates and four AZO-S isolates of $D$. bryoniae tested. Sequence analysis revealed the presence of a single nucleotide substitution of cytosine for guanine (GGT to GCT) at the amino acid codon 143 in all AZO-R isolates (Fig. 1). This nucleotide substitution was not present in any of the AZO-S isolates tested (Fig. 1).

Genomic DNA allele-specific PCR. The AZO-R allele-specific primer pair DB-F/DB-RR consistently amplified a 165-bp PCR

Table 2. Oligonucleotide primers used in this study

\begin{tabular}{llll}
\hline Primer name & \multicolumn{1}{c}{ Sequence } & \multicolumn{1}{c}{ Feature $^{\mathbf{a}}$} & \multicolumn{1}{c}{ Reference } \\
\hline FG143 & 5' GCA GCT TTA GCC CTT GGT AA 3' & Partial $c y t b$ covering codon 143 & Patel et al. (20) \\
RG143 & 5' CTG CGC TAT TTT TAA TAT AGG TTC CTG 3' & Partial $c y t$ c covering codon 143 & Patel et al. (20) \\
DB-F & 5' CGT ATA GTC TCT GAG GAA CC 3' & Forward primer for AZO-R and AZO-S & This study \\
DB-RR & 5' GCA GAT GTC ATT ATG AGG 3' & AZO-R allele specific reverse primer & This study \\
DB-RS & 5' GCA GAT GTC ATT ATG AGC 3' & AZO-S allele specific reverse primer & This study \\
DB-FC & 5' CAG ATG TCA TTA TGA GGT GCT ACA 3' & Forward primer for both alleles & This study \\
DB-RC & 5' CCG CTT CAC AAA GGC CTA TAA 3' & Reverse primer for both alleles & This study \\
\hline
\end{tabular}

a Abbreviations: cyt $b=$ cytochrome b gene, AZO-R = azoxystrobin-resistant, and AZO-S = azoxystrobin-sensitive.

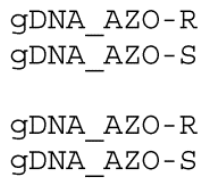

TTTGATAACAAGATTAAATACTACTTTTTTACAATAAGTAAGTTTGTATGTGCTGCCCTA TTTGATAACAAGATTAAATACTACTTTTTTACAATAAGTAAGTTTGTATGTGCTGCCCTA

CGGGCAGATGTCATTATGAGCTGCTACAGTTAAAAAGGCGAAGTAATAGCTGTAGTAAAA CGGGCAGATGTCATTATGAGGTGCTACAGTTAAAAAGGCGAAGTAATAGCTGTAGTAAAA

Fig. 1. Cytochrome b sequences from genomic DNA (gDNA) of azoxystrobin-resistant (AZO-R) and -sensitive (AZO-S) isolates of Didymella bryoniae. Highlighted letters indicate the nucleotide change at amino acid position 143 that confers resistance to AZO. 
product from nine AZO-R isolates of $D$. bryoniae tested but not from any of the nine AZO-S isolates (Fig. 2). The AZO-S allelespecific primer pair DB-F/DB-RS consistently amplified a 165-bp PCR product from nine AZO-S isolates of $D$. bryoniae but not from any of the nine AZO-R isolates tested (Fig. 3). Both alleles were consistently amplified with primer set DB-FC/DB-RC (Fig. 4). DNA of Pythium ultimum, Phytophthora capsici, F. oxysporum f. sp. niveum, $S$. rolfsii, $R$. solani, or Pseudoperonospora cubensis were not amplified by primer pairs DB-FC/DB-RC (Fig. 4) and DB-F/DB-RR or DB-F/DB-RS (data not shown).

\section{Discussion}

In this study, a fragment of the $c y t b$ gene containing the G143A site was amplified in genomic DNA of $D$. bryoniae. The highly conserved nature of the cyt $b$ region containing the G143A site
$(7,20)$ allowed us to use previously published primer sets for closely related ascomycetes to screen the $c y t b$ gene of $D$. bryoniae. Prior to this study, there were no published $c y t b$ sequences for $D$. bryoniae. The G143A mutation was detected in all AZO-R isolates tested but not in AZO-S isolates. These results are in agreement with a previous report that the G143A mutation is present in and responsible for resistance to QoI fungicides in D. bryoniae (5). These findings also further validate the results obtained from the conidial germination assays used to characterize isolates as either AZO-R or AZO-S, because the G143A mutation was present in all AZO-R phenotypes and absent in all AZO-S phenotypes.

Molecular methods to differentially detect $D$. bryoniae resistant to QoI fungicides have not been reported, though several qualitative and quantitative molecular techniques have been used to iden-

RESISTANT

SENSITIVE

\section{R1 R2 R3 R4 R5 R6 R7 R8 R9 S1 S2 S3 S4 S5 S6 S7 S8 S9 C}

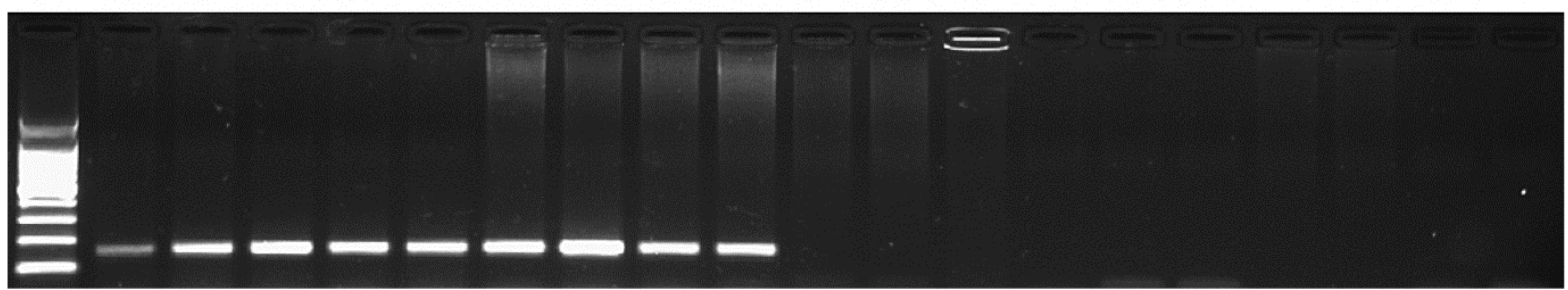

Fig. 2. Allele-specific polymerase chain reaction using genomic DNA with primer pair DB-F/DB-RR for the detection of azoxystrobin-resistant (AZO-R) isolates of Didymella bryoniae. AZO-sensitive isolates: S1 = UR3-5, S2 = R501-3-1, S3 = C2-8, S4 = R204-1-1, S5 = R501-3-2, S6 = R501-3-4, S7 = R501-3-5, S8 = R606-3-1, S9 = R606-3-4. AZO-R isolates: R1 = C2-1, R2 = C5-1, R3 = B105-3-3, R4 = UR5-9, R5 = C2-5, R6 = C2-7, R7 = C5-7, R8 = C5-8, R9 = UR3-1. C = negative control, M = 1-kb DNA ladder (Qiagen).

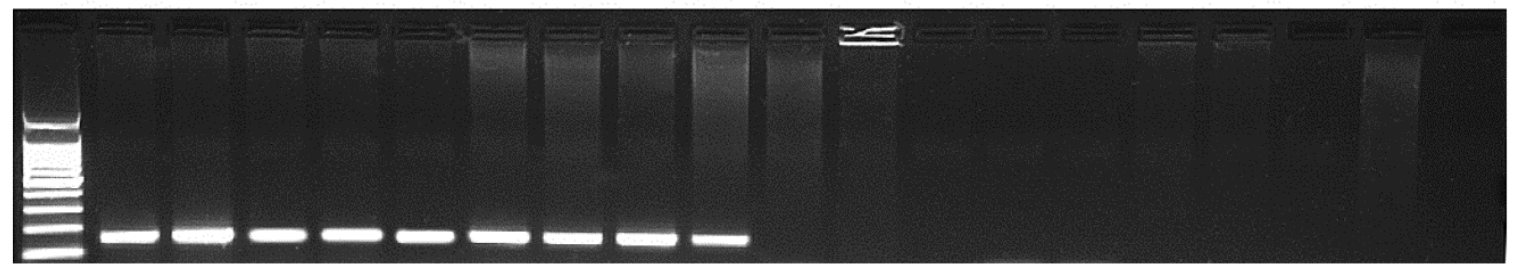

Fig. 3. Allele-specific polymerase chain reaction using genomic DNA with primer pair DB-F/DB-RS for the detection of azoxystrobin-sensitive (AZO-S) isolates of Didymella bryoniae. AZO-S isolates: S1 = UR3-5, S2 = R501-3-1, S3 = C2-8, S4 = R204-1-1, S5 = R501-3-2, S6 = R501-3-4, S7 = R501-3-5, S8 = R606-3-1, S9 = R606-3-4. AZOresistant isolates: $\mathrm{R} 1=\mathrm{C} 2-1, \mathrm{R} 2=\mathrm{C} 5-1, \mathrm{R} 3=\mathrm{B} 105-3-3, \mathrm{R} 4=\mathrm{UR} 5-9, \mathrm{R} 5=\mathrm{C} 2-5, \mathrm{R} 6=\mathrm{C} 2-7, \mathrm{R} 7=\mathrm{C} 5-7, \mathrm{R} 8=\mathrm{C} 5-8, \mathrm{R} 9=\mathrm{UR} 3-1 . \mathrm{C}=$ negative control, $\mathrm{M}=1-\mathrm{kb}$ DNA ladder (Qiagen).

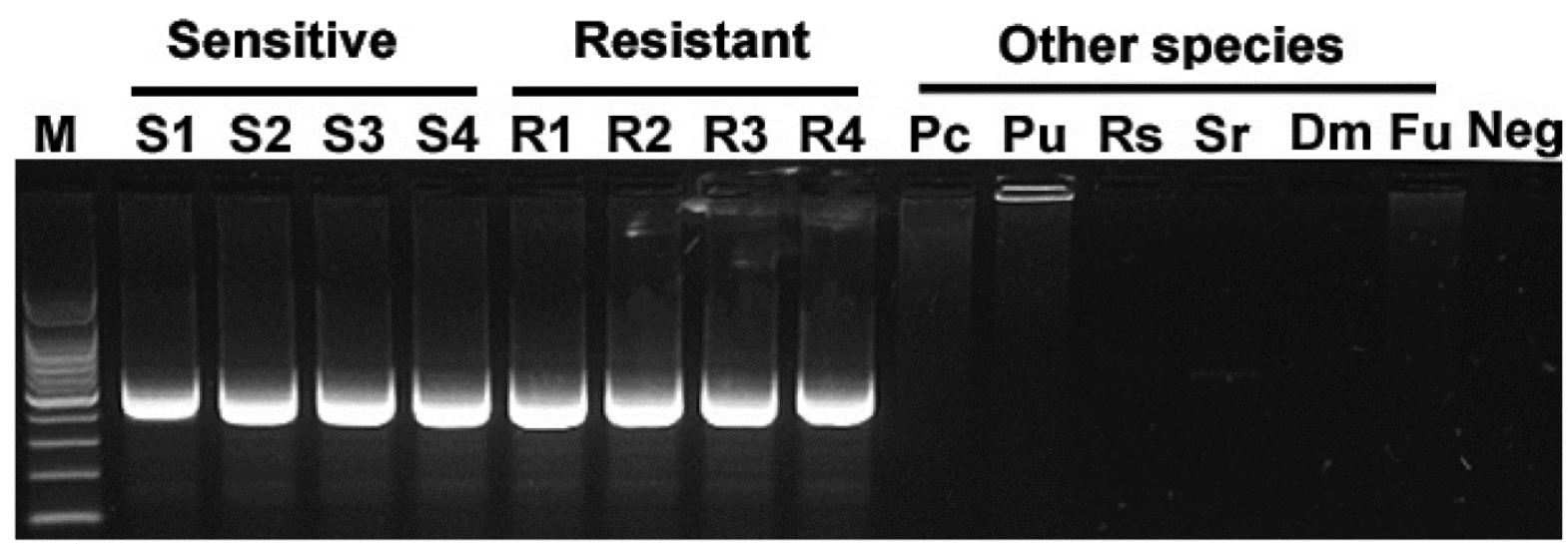

Fig. 4. Allele-specific polymerase chain reaction using genomic DNA with primer pair DB-FC/DB-RC for the detection of azoxystrobin-sensitive (AZO-S) and -resistant (AZO$\mathrm{R}$ ) isolates of Didymella bryoniae. AZO-S isolates: $\mathrm{S} 1=\mathrm{UR} 3-5, \mathrm{~S} 2=\mathrm{R} 501-3-2, \mathrm{~S} 3=\mathrm{C} 2-8, \mathrm{~S} 4=\mathrm{R} 204-1-1$. AZO-R isolates: R1 = C2-1, R2 = C5-1, R3 = B105-3-3, R4 = UR5-9. Other species: $\mathrm{Pc}=$ Phytophthora capsici, $\mathrm{Pu}=$ Pythium ultimum, $\mathrm{Rs}=$ Rhizoctonia solani, $\mathrm{Sr}=$ Sclerotium rolfsii, $\mathrm{Dm}=$ Pseudoperonospora cubensis, $\mathrm{Fu}=$ Fusarium oxysporum f. sp. niveum. Neg = negative control, $\mathrm{M}=100 \mathrm{bp}$ DNA ladder (Qiagen). 
tify resistance to QoI fungicides in a number of other plant pathogenic fungi $(1-3,8,14,16,17,24)$. Of those techniques, allelespecific PCR has been used for both qualitative and quantitative detection of QoI resistance in Blumeria graminis f. sp. tritici, Alternaria spp., Venturia inaequalis, and Botrytis cinerea $(2,3,8$, 16,17). In the present study, allele-specific PCR was used to detect AZO resistance in isolates of $D$. bryoniae. In addition to primers designed to amplify the AZO-R and AZO-S alleles, a third primer set was designed that amplified both allele types as a control. All allele-specific primer sets developed in this study were determined to be specific to $D$. bryoniae, because they did not amplify any other fungal species tested.

To our knowledge, this is the first report in which molecularbased detection has been developed to identify resistance to AZO in D. bryoniae. Traditionally, conidial germination assays have been employed for AZO resistance detection in $D$. bryoniae $(10,19,22,23)$. Although conidial germination assays are useful in AZO resistance detection, these assays can be time consuming and laborious. The allele-specific PCR assays significantly decrease time and labor required to detect AZO resistance in $D$. bryoniae. The results of this study also provide the basis for development of a quantitative molecular assay that will be useful in studying epidemiological aspects of GSB. However, further research is needed in order to confirm that the allele-specific PCR protocols developed in this study can be used to successfully detect AZO resistance in GSB-infected plant samples.

\section{Acknowledgments}

We thank B. Evans, K. Lewis, and M. Purvis for providing technical assistance. Financial support by a United States Department of Agriculture NIFA grant for integrated management of vegetable diseases is appreciated.

\section{Literature Cited}

1. Delgado, J. A., Lynnes, T. C., Meinhardt, S. W., Wise, K. A., Gudmestad, N. C., Bradley, C. A., Markell, S. G., and Goswami, R. S. 2013. Identification of the mutation responsible for resistance to QoI fungicides and its detection in Ascochyta rabiei (teleomorph Didymella rabiei). Plant Pathol. 62:688-697.

2. Fontaine, S., Remuson, F., Fraissinet-Tachet, L., Micoud, A., Marmeisse, R., and Melayah, D. 2009. Monitoring of Venturia inaequalis harbouring the QoI resistance G143A mutation in French orchards as revealed by PCR assays. Pest Manage. Sci. 65:74-81.

3. Fraaije, B. A., Butters, J. A., Coelho, J. M., Jones, D. R., and Hollomon, D. W. 2002. Following the dynamics of strobilurin resistance in Blumeria graminis f. sp. tritici using quantitative allele-specific real-time PCR measurements with the fluorescent dye SYBR green I. Plant Pathol. 51:45.

4. FRAC (Fungicide Resistance Action Committee). 2006. Mutations associated with QoI-resistance. www.frac.info

5. FRAC (Fungicide Resistance Action Committee). 2012. List of pathogens with field resistance towards QoI fungicides. www.frac.info

6. Gisi, U., Sierotzki, H., Cook, A., and McCaffery, A. 2002. Mechanisms influencing the evolution of resistance to Qo inhibitor fungicides. Pest Manage. Sci. 58:859-867.

7. Grasso, V., Palermo, S., Sierotzki, H., Garibaldi, A., and Gisi, U. 2006. Cytochrome $\mathrm{b}$ gene structure and consequences for resistance to Qo inhibitor fungicides in plant pathogens. Pest Manage. Sci. 62:465-472.

8. Jiang, J., Ding, L., Michailides, T. J., Li, H., and Ma, Z. 2009. Molecular characterization of field azoxystrobin-resistant isolates of Botrytis cinerea. Pestic. Biochem. Physiol. 93:72-76.

9. Keinath, A. P. 1995. Fungicide timing for optimum management of gummy stem blight epidemics on watermelon. Plant Dis. 79:354-358.

10. Keinath, A. P. 2009. Sensitivity to azoxystrobin in Didymella bryoniae isolates collected before and after field use of strobilurin fungicides. Pest Manage. Sci. 65:1090-1096.

11. Kim, Y. S., Dixon, E. W., Vincelli, P., and Farman, M. L. 2003. Field resistance to strobilurin (QoI) fungicides in Pyricularia grisea caused by mutations in the mitochondrial cytochrome b gene. Phytopathology 93:891900 .

12. Langston, D. B., Jr. 2002. Quadris resistance in gummy stem blight confirmed. Ga. Ext. Veg. News 2:1-2.

13. Langston, D. B., Jr., Lewis, K. L., and Jennings, W. T. 2000. Evaluation of fungicides and spray programs for control of gummy stem blight on watermelon. Fungic. Nematicide Tests 55:291.

14. Lesniak, K. E., Proffer, T. J., Beckerman, J. L., Sundin, G. W. 2011. Occurrence of QoI resistance and detection of the G143A mutation in Michigan populations of Venturia inaequalis. Plant Dis. 95:927-934.

15. Ma, Z., Felts, D., and Michailides, T. J. 2003. Resistance to azoxystrobin in Alternaria isolates from pistachio in California. Pestic. Biochem. Physiol. 77:66-74.

16. Ma, Z., and Michailides, T. J. 2004. An allele-specific PCR assay for detecting azoxystrobin-resistant Alternaria isolates from pistachio in California. J. Phytopathol. 152:118-121.

17. Michalecka, M., Malinowski, T., Broniarek-Niemiec, A., and Bielenin, A. 2011. Real-time PCR assay with SNP-specific primers for the detection of a G143A mutation level in Venturia inaequalis field populations. J. Phytopathol. 159:569-578.

18. Miessner, S., and Stammler, G. 2010. Monilinia laxa, M. fructigena and M. fructicola: Risk estimation of resistance to QoI fungicides and identification of species with cytochrome b gene sequences. J. Plant Dis. Prot. 4:162-167.

19. Olaya, G., and Holm, A. 2001. Sensitivity of Didymella bryoniae isolates to azoxystrobin. (Abstr.) Phytopathology 91:S67.

20. Patel, J. S., Meinhardt, S. W., Sierotzki, H., Stammler, G., Gudmestad, N. C., and Adhikari, T. B. 2011. A two-step molecular detection method for Pyrenophora tritici-repentis isolates insensitive to QoI fungicides. Plant Dis. 95:1558-1564.

21. Peever, T. L., and Milgroom, M. G. 1995. Fungicide resistance - lessons for herbicide resistance management? Weed Technol. 9:840-849.

22. Stevenson, K. L., Seebold, K. W., and Langston, D. B., Jr. 2004. Resistance to azoxystrobin in the gummy stem blight pathogen documented in Georgia. Plant Health Progress. Online publication. doi:10.1094/PHP-2004-1207-01RS

23. Thomas, A., Langston, D. B., Jr., Sanders, H. F., and Stevenson, K. L. 2012. Relationship between fungicide sensitivity and control of gummy stem blight of watermelon under field conditions. Plant Dis. 96:1780-1784.

24. Wei, C. Z., Katoh, H., Nishimura, K., and Ishii, H. 2009. Site-directed mutagenesis of the cytochrome $b$ gene and development of diagnostic methods for identifying QoI resistance of rice blast fungus. Pest Manage. Sci. 65:1344-1351. 